\title{
Chapter 5 \\ Song: The Learned Language of Three Major Bird Clades
}

\author{
Martin Päckert
}

\begin{abstract}
Vocal learning has evolved several times independently in mammals and three major orders of birds. Of these only hummingbirds and passerine birds have complex songs, whereas the large vocal repertoires of parrots comprise various call types associated with different behavioral contexts. Generally, bird song has two major functions: territorial defense and mate attraction. In the latter context, particularly in songbirds (Oscines), the evolution of male song repertoires has strongly been driven by sexual selection: Song complexity and repertoire size have been shown to be indicators of male quality and are thus crucial traits for female choice. Today, the age of phylogenetics provides new methods for the study of the mode and tempo of organismic diversification and of trait evolution, e.g., of vocal learning. As a striking result, song learning seems to be associated with species richness across the avian tree of life. This provided recent evidence for the theory that song learning can act as a pacemaker of evolution. The spatial variation of song dialects is often correlated with genetic diversification. Extreme cases are small isolated populations, for example, on islands. In the field, the effect of song diversification as a barrier for gene flow can best be observed in zones of secondary contact between close relatives. Even in cases of hybridization, differences of song might affect female choice and thus lead to assortative mating and prevent gene flow in one or even in both directions. These are probably the most exciting case studies, where speciation in action (or in reverse) can be studied in the wild.
\end{abstract}

Keywords Dialects $\cdot$ Cultural evolution $\cdot$ Passeriformes $\cdot$ Sexual selection

\footnotetext{
M. Päckert (凹)

Senckenberg Natural History Collections, Dresden, Germany

e-mail: martin.paeckert@senckenberg.de 


\subsection{Eager Birds: The Advanced Learners}

The capacity of vocal learning is found only in three larger branches of the avian tree of life: hummingbirds (Trochilidae), parrots (Psittacidae), and perching birds (Passeriformes). These three advanced learners represent quite different groups of birds with respect to anatomy, behavior, and ecology. Indeed, parrots and passerines are closest relatives, but hummingbirds belong to a totally different branch of the bird phylogeny: They are sister to swifts (Apodidae) that dispose of rather simplestructured vocal repertoires. This basically means that in birds, vocal learning and the associated brain structures have evolved at least twice independently (Jarvis 2006; Suh et al. 2011; Nowicki and Searcy 2014). Even in perching birds (Passeriformes), not every species is capable of vocal learning: Only the true songbirds of the suborder Passeri are the real vocal learners: the Oscines. Apart from this species-rich group, two tropical suborders of passerines dispose of mainly innate vocalizations: the New Zealand wrens (Acanthisittidae) and the highly diverse tyrant flycatchers (Tyranni, also called Suboscines). Learning capacity has been shown to correspond with similarities in forebrain areas of hummingbirds and Oscines that were not found in their non-learning sister groups (swifts and Suboscines; Gahr 2000).

Of the three vocal learners, passerines have by far the most complex vocalizations with respect to the diversity and combinations of single sounds in complex compositions such as territorial songs. Let's say passerines are the greatest performers. For their immense diversity, passerine vocal repertoires probably show the greatest variation in space and time. Therefore, in the following, I mainly focus on these most eager learners among birds.

\subsection{Passerine Song}

Almost all passerine birds have a large repertoire of highly diverse vocalizations displayed in various behavioral contexts. We distinguish two main classes of vocalizations: calls and songs (Catchpole and Slater 1995). Calls are simple rather short vocalizations for communication among mates, rivals, parents and young, within a flock and even among different species like in case of alarm calls (Marler 2004b). The characteristic "rain calls" of chaffinches (Fig. 5.1) are highly variable among regions, even among different quarters of a city. Their function is not fully understood; however, for the resemblance of these regularly repeated buzzing sounds with those of other finch species, they have sometimes been considered an energy-saving rudimentary song type (Constantine 2006).

In contrast, songs are long and complex vocalizations that in many species are composed of many different notes and motifs. The sequential order of notes or song parts (syntax) is a characteristic for most passerine species. Generally, the single bird displays many songs in succession during song bouts that can last over several 


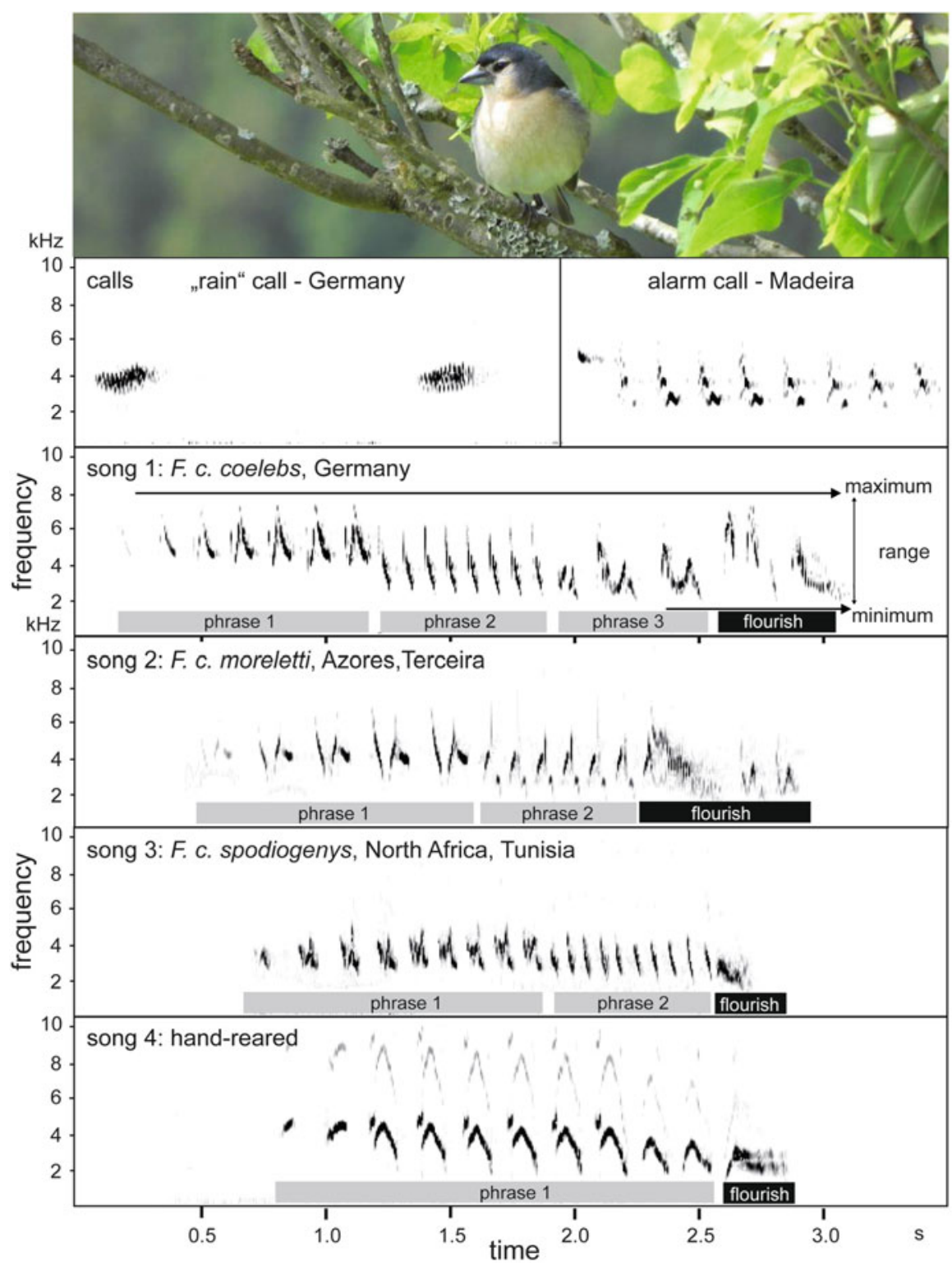

Fig. 5.1 Sonagraphic analysis of bird vocalizations. A sonagram is a spectrographic image of sound events, i.e., a plot of frequency ( $y$-axis) versus time ( $x$-axis). Different frequency and time parameters can be measured for scientific analysis (see song 1). Each sound event (note) is represented by a continuous black line. The plate shows different calls and dialect song types of the Common Chaffinch Fringilla coelebs (picture: F. c. moreletti, São Miguel Azores; M. Päckert 2017). Typical chaffinch songs are composed of different phrases (stereotyped repetitions of one element or motif) and a variable terminal flourish. All recordings of M. Päckert except song 3 (S. Eck) and song 4: a hand-reared bird recorded by Thorpe in the year 1954 (from Marler and Slabbekoorn 2004) 
minutes. The successive songs can have more or less the same structure like in the Common Chaffinch Fringilla coelebs (Fig. 5.1), or they can show a great variation of many different song types like in the Common Blackbird Turdus merula or the Common Starling Sturnus vulgaris. The entirety of all different song types of a bird is termed a repertoire. Unlike calls, songs have two main functions and receivers: territorial defense in communication between males and mate attraction in communication between males and females. As a consequence, territorial song is often displayed by males only, mainly throughout the breeding season and rarely heard, for example, in the wintering grounds. That seasonality and male monopoly of song display is more or less the rule in the temperate parts of the Northern Hemisphere, whereas in the Tropics the situation is quite different. There, a fascinating variant of vocal display can be observed: duetting of mated males and females. It has been considered a rare phenomenon, but in fact duetting has been observed in about 400 species from about 40\% of all bird families (Hall 2009; Logue and Krupp 2016). Not to forget that duetting is also present in the two other eager learners among birds, the hummingbirds (Ficken et al. 2000) and the parrots (Dahlin and Wright 2012). Strikingly, duetting is almost exclusively limited to tropical species, and a recent study suggested that it seems to be firmly associated with the absence of migration rather than with sexual dichromatism, for example (Logue and Hall 2014). This particular behavior is not limited to male-female interaction: For example, Whitebrowed Sparrow-Weavers Plocepasser mahali, cooperative breeders from sub-Saharan Africa, regularly perform complex group duets with the dominant male performing solo displays (Voigt et al. 2006). Not least, increasing knowledge of duetting behavior has challenged the paradigm that in most passerines only males would sing. In fact, current studies showed that female song is much more common than previously believed and present in at least $71 \%$ of all songbird species (Odom et al. 2014; Amy et al. 2015; Price 2015). Though knowledge on female song is still scarce, it is beyond dispute that females have played a key role in avian song evolution, because it is them who generally decide about mating success of males.

\subsection{The Best Singer Takes It All: Female Preference and Sexual Selection}

For their different functions in behavioral interaction within and among sexes, bird songs are considered both armaments and sexually selected ornaments (Tobias et al. 2011). It was indeed Darwin, who first developed the theory of sexual selection and considered that vocalizations could play a major role for female choice. Originally, Darwin's view on female choice was merely an "aesthetic" conception of bird song and this has been immediately criticized by Wallace, who postulated that from the perspective of females, song would be an indicator of male vigor and viability (review in Prum 2012). 
There is good knowledge that across a broad spectrum of vertebrate species, mate preference is learned by both males and females during a phase of sexual imprinting (Irwin and Price 2009; Verzijden et al. 2012). Also in birds, females discriminate between different variations of songs, and like male song female choice is learned from different tutors. Likewise, female birds were shown to react more positively and intensively toward song types of their own mate (O'Loghlen and Beecher 1997) or toward the local dialect from their own population (Danner et al. 2011). Furthermore, in many species like the Song Sparrow Melospiza melodia, female preference is firmly associated with repertoire size (Reid et al. 2004). Another famous example comes from reed warblers of the genus Acrocephalus: Their long warbling songs displayed from dense riverine vegetation can comprise a multitude of different notes. For example, Marsh Warblers A. palustris are great learners, because in their African wintering grounds, they can pick up vocalizations of many tropical bird species and remember them next spring in their Eurasian breeding territories (Dowsett-Lemaire 1979). Likewise, a reed warbler male in its first year can easily double its vocal repertoire by mimicking other species (Kroodsma 2004: Box 18). Repertoire size and composition can accordingly change between successive breeding seasons (Wegrzyn and Leniowski 2009). Female reed warblers seem to have a preference for long and complex songs, because apparently the males with the largest repertoires get mated first and have a greater breeding success (Catchpole 1980, 1986; Catchpole and Leisler 1996; Kroodsma 2004: Box 17; Darolová et al. 2012). These classical studies became a textbook example for sexual selection on repertoire size. However, reservations are standing, because mating and breeding success are influenced by a few more factors than female choice only. About 10 years later, Forstmeier and Leisler (2004) meticulously repeated those experiments by Catchpole and his team on Great Reed Warblers A. arundinaceus and came to an astonishing result: In the same Swedish population, male repertoire sizes were positively correlated with male pairing success and clutch size in the 1980s, but not in the 1990s. The authors suggested that recent population decline of Scandinavian Great Reed Warblers might have changed the role of territory quality and thus of repertoire sizes as a putative indicator. We will later see that a change of ecological factors (both biotic and abiotic) might lead to remarkable changes of local song types. However, despite the critical reevaluation of Catchpole's studies (see also Darolová et al. 2012), there is still good evidence that female birds can infer reliable information on male quality from their songs (Nowicki et al. 1998). The so-called good-genes hypothesis originally referred only to visual ornamental traits such as coloration. However, soon the assumption was made that this hypothesis would apply to bird vocalizations, too. For example, according to general belief, animals tend to avoid inbreeding depression, i.e., they avoid mating among members of close kinship or even with individuals from an inbred population (Pusey and Wolf 1996). Just recently, researchers found out that captive female Atlantic Canaries Serinus canaria indeed discriminate between inbred and outbred birds by their different songs. As a consequence, they mated less often with an inbred male, and, if they did, breeding success was lower than that of couples with an outbred male (deBoer et al. 2016). We will see that male 
quality does not relate only to inherited but also to acquired traits in a later paragraph; but let's first step back on a brief walk through history of bioacoustic research.

\subsection{How It All Began: A Brief History of Bioacoustic Studies}

In the second half of the twentieth century, experimental studies on song learning in birds were developed by behaviorist scholars like the neurobiologist Fernando Nottebohm or the zoologist William H. Thorpe, who pursued a comparative ethological approach. He was a pioneer of bioacoustic studies, and he was also the first scientist to use spectrography (Fig. 5.1) — a newly emerging technique in these days - for analysis of bird song (Marler 2004a). Generally, the core question of the early behaviorist studies was to disentangle learned and innate components of bird song; however, their experimental designs differed.

For example, classical neuroscientific experiments focused on test birds that were surgically deafened a few days after hatching (Nottebohm 1970) or whose innervation of the vocal apparatus (the syrinx) had been manipulated (Nottebohm 1970, 1971). Ethological experiments had a more simplified setting: They studied cage birds that were hand-reared in acoustic isolation. For the deprived situation of the test birds, these studies later became famous as Kaspar-Hauser experiments, named after the mysterious foundling from Nürnberg of the early nineteenth century. The simple design with completely isolated individuals was expected to unmistakably unveil the ancestral innate structure of a bird's song. However, in a second step, scientists tried to find out more about a birds learning capacity by exposing the test birds to different tutors (of the same and of different species), to tape recordings or even to human whistles that resulted in exact copies of a German folk tune by Eurasian Bullfinches Pyrrhula pyrrhula (Nicolai et al. 2014). The probably most popular model species of early ethologists was the Common Chaffinch (review in Riebel et al. 2015). Figure 5.1 shows the comparison of two fully developed songs from wild birds with a recording of a hand-reared bird by Thorpe (1958). Evidently, the KasparHauser song is more simplified in structure and note variation, and it lacks the characteristic partition into distinct phrases. However, the test bird's song still bares striking similarities with the song of wild birds: The frequency course is slightly descending toward the simplified terminal flourish at the end of the strophe.

Based on their experimental results, most scientists agreed that birds have a sensitive phase for the acquisition of fully developed (crystallized) song (Nottebohm $1968,1969,1970)$. The duration of this phase can vary extremely among species (Hultsch and Todt 2004) from only a few days in the nest with the father as tutor to the first breeding season with further tutorial input from the territory neighbor. These "age-limited learners" (or "close-ended learners") are opposed to the so-called "open-ended learners" among them the Common Starling (Eens et al. 1992). 
However, lifelong learning is also known from the other two eager learners of birds: It has been shown for some hummingbird species (Araya-Salas and Wright 2013) and of course for parrots above all from the studies of Irene Pepperberg on Grey Parrots Psittacus erithacus. Her most famous parrot Alex proved to be capable even of referential learning of human speech (Pepperberg 2004, 2010). Generally, learning mode seems to be correlated with repertoire size in a way that open-ended learners have the larger repertoires (Creanza et al. 2016) - which is not too surprising, because they simply have more time to increase their "vocabulary" annually. The cage experiment was soon complemented by a great number of studies on wild bird populations in the field, and their basic conclusion can be summarized in brief: Bird song is subject to cultural evolution. Because several different cultural traits, such as song learning or female mating preference are involved and mutually affect each other, that complex evolutionary process was recently suggested to end up in the reconstruction of a cultural niche (Creanza et al. 2016).

\subsection{Telltale Songs: Evolution and Phylogenetic Information of Vocalizations}

As one result of cultural evolution, the song of a bird species bares ultimate diagnostic traits that allow for exact species determination by the scientist and for effective species recognition among the birds themselves. Nevertheless, species of the same genus, for example, may share common song features that clearly indicate close kinship. Kinglets are among the smallest passerines, and therefore most species have a rather high-pitched voice. All of the six Regulus species have clearly structured songs that are composed of two or three parts (Martens et al. 1998; Päckert et al. 2003). Each of these parts is defined by characteristic sound constraints: For example, all species share one song part (Fig. 5.2) that is steadily increasing within the same frequency range. Because this rising sequence contains similar whistling notes in all species, it can be considered an ancestral song part that all kinglet species have in common. Only three species complete their songs with a terminal flourish, and a single Goldcrest $R$. regulus male, for example, can have about 20 different individual variations of this end part. The molecular family tree of kinglets in Fig. 5.2 shows that the three flourish-singers are closest relatives and that among these only the Goldcrest and its sister species $R$. goodfellowi on Taiwan share a common song introduction. This basically means that some components of song give us a clue on relatedness, whereas others do not. In terms of scientists, we say that songs carry phylogenetic information (Rheindt et al. 2014). This has been demonstrated for treecreepers Certhia (Tietze et al. 2008) and leaf warblers, Phylloscopidae (Päckert et al. 2004; Mahler and Gil 2009; Tietze et al. 2015). These case studies also showed that highest phylogenetic signal was found for innate components of songs like, for example, calllike elements or the general syntax. For example, like in the previous Chaffinch example, hand-reared Goldcrests always displayed the typical bi- or tripartite 


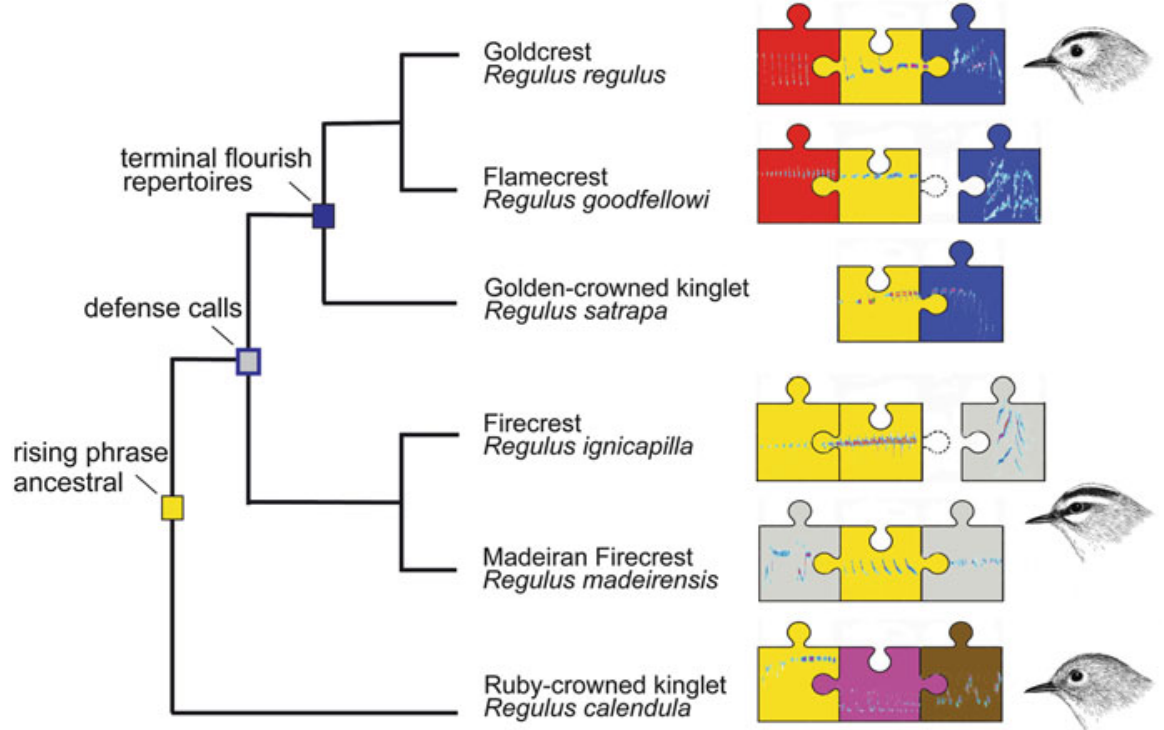

Fig. 5.2 Evolution of territorial song in kinglets Regulus; the schematized molecular tree is modified after Päckert et al. (2003, 2009). For each species, the characteristic and invariable bior tripartite song structure is shown as jigsaw puzzles. Homologous song parts are indicated by pieces of the puzzle with the same color with typical sonagrams included. Gray pieces indicate innate vocalizations such as calls integrated in the song of some species. Two species only occasionally attach a terminal part to their song (unconnected pieces): $R$. ignicapilla (invariable terminal call) and $R$. goodfellowi (variable terminal flourish). In contrast, songs of $R$. regulus and $R$. satrapa regularly include a variable terminal flourish (connected pieces). From the many diverse dialects of the Goldcrest, a recording from Japan (Hokkaido; $R$. regulus japonensis) was chosen for the strong similarities of the yellow phrase (repetition of whistle notes) with that of North American R. satrapa (see Martens et al. 1998)

partitioned song with a simple flourish motif at the end (Thaler 1990). On the other hand, Common Firecrests $R$. ignicapilla have rather simple songs that can contain call elements usually displayed in a different behavioral context, e.g., in close aggressive contact. Only very occasionally Common Firecrests end their songs with such calls that pretty much resemble single motifs in the terminal flourish repertoires of $R$. regulus and $R$. satrapa. In so far, crests and kinglets provide a stunning example of vocal evolution of complex song structures and repertoires derived from ancestral simple vocalizations such as calls (Fig. 5.2).

\subsection{Vocal Learning as a Pacemaker of Evolution}

Strikingly, passerines represent by far the greatest part of the global avian biodiversity: About $60 \%$ of all bird species belong to the order of Passeriformes. At the same time, their top position in the avian tree of life makes passerines the "youngest" bird 
order, and on average they have higher diversification rates than nonpasserines (Jetz et al. 2012). This basically means that the immense passerine species richness has evolved over a rather short period of time compared to other bird orders. Since long, ornithologists and evolutionary biologists have been trying to find an explanation for this overwhelming success of passerine birds. It was the famous evolutionary biologist Ernst Mayr, who came up first with the idea that evolutionary change can be effectively caused by newly acquired behavior (reviewed in Corning 2014). Later, it was Gerhard Thielcke $(1970,1972)$, another pioneer in the field of bioacoustics, who adopted Mayr's ideas and hypothesized that song learning can be a "pacemaker of evolution." Like behaviorists of the 1960s, Thielcke based his ideas on the results of Kaspar-Hauser experiments that he carried out with captive treecreepers of species Certhia familiaris and C. brachydactyla. Since then, the pacemaker theory has been lively and controversially discussed, but the original idea was kept alive: If songs of two birds differ to a certain degree, they will not consider each other as a member of their own species, i.e., song variation affects species recognition in both males and females. Therefore, avian vocalizations can be an effective premating barrier and cause reproductive isolation (to a certain degree) among closest relatives (Martens 1996, 1998).

These theories have been recently put to test with modern analytical methods. The basic question was: Are song-learners greater speciators than those birds that do not learn? This can be done in a totally theoretical approach using simulations under different evolutionary models. To put it simple, in theory, the learning model always produced greater mean differentiation of songs as a response of males to female preferences and sexual selection (Lachlan and Servedio 2004). Further evidence came from phylogenetic studies posing the basic question: Do song-learners generate more branches of the avian tree of life over time than non-learners? A comparison of two Neotropical passerine families yielded two striking results (Mason et al. 2017): Each burst of speciation (i.e., accelerated emergence of new branches) was associated with increased diversification of songs in both groups. However, the mean speciation rates were greater in the oscine study family with learned songs (tanagers and allies, Thraupidae) than in the non-learning suboscine study family (antbirds, Thamnophilidae).

\subsection{Dialects: Spatial Variation}

In analogy to human language, spatially separated song types of the same species are called dialects. Possibly the most comprehensive fine-scale monitoring of passerine song dialects is available for the Yellowhammer Emberiza citrinella: Across its European breeding range, a mosaic distribution of distinct song types and the corresponding dialect boundaries has been documented over the last decades (Petrusková et al. 2015). Just recently, an exciting newsflash announced that lost birdsong had been discovered in introduced Yellowhammer populations from New Zealand. There, far beyond the species' native breeding range on the other 
side of the globe, some dialect types were registered that apparently went lost in the British area of origin of the species (Pipek et al. 2017). In analogy to population genetic processes, such timely change of local song repertoires has been considered a merely stochastic effect termed cultural drift (Lynch 1996). That means just by chance, rare song types become either fixed in a local population, or they do completely vanish from the local repertoire. As stochastic processes have greatest effects on small samplings, cultural drift is believed to act most effectively on small isolated populations such as on remote islands (Potvin and Clegg 2015). However, under the assumption of neutral evolution, no general pattern or directionality of song evolution on islands can be hypothesized, and this has been confirmed by some empirical comparative studies (Baker et al. 2006). Taking the Macaronesian archipelagic chain as an example, we find both increase of acoustic variation and greater song repertoires on islands like in Goldcrests on the Azores (Päckert and Martens 2004) as well as impoverishment of song and loss of syntactical structure in Common Chaffinch island populations (Lachlan et al. 2013). Like on oceanic islands, cultural drift has been suggested to act on passerine song divergence among sky islands such as isolated mountain chains (Purushotham and Robin 2016).

An extreme case of stochastic effect on island song repertoires is so-called withdrawal of learning. This assumes a scenario where a small group of young birds without fully crystallized song colonizes an island and in succession develops a specific island song type composed of innate vocalizations (Thielcke 1970). In a way, this theory postulates a Kaspar-Hauser experiment under natural conditions. Madeira Firecrests $R$. madeirensis provide a striking example. In contrast to songs of European $R$. ignicapilla, songs on the island of Madeira are composed of innate vocalizations only (Fig. 5.2). The typical ascending kinglet phrase is accompanied by two different call types that are also displayed in different behavioral contexts: contact calls at the beginning and aggressive calls at the end of the song (Päckert et al. 2001; Constantine 2006).

All predictions on the effect of cultural drift are based on the a priori assumption of merely stochastic processes on selectively neutral variants of song. However, as we have already seen, sexual selection plays a key role on individual and spatial song variation and on the evolution of bird song in general. Moreover, there are further environmental selective pressures shaping song variation within and among species.

\subsection{Competition for Acoustic Space: The Role of Ecology}

A strong pressure of natural selection on bird vocalizations is ecology, i.e., habitat characteristics, community structure, intra- and interspecific concurrence, etc. (reviews in: Catchpole and Slater 1995: pp. 71-92; Slabbekoorn and Smith 2002; Slabbekoorn 2004). Optimal sound transmission strongly depends on habitat characteristics above all on vegetation density. This is actually one reason why many birds choose elevated song perches to bring their message across densely vegetated areas. In fact, in dense tropical forests, songs of closely related passerine species 
differ in predictable adaptive parameters according to perch height and vegetation cover (Nemeth et al. 2001; Barker and Menill 2009). Apparently, in a given local assemblage, different bird species compete for acoustic space (Luther 2009; Azar and Bell 2016). For the same reasons, song of one and the same species can strongly vary in frequency and time characteristics among open habitat and densely covered vegetation (Hunter and Krebs 1979). In high mountain systems such as the Andes and the Himalayas, strong ecological segregation of closely related species has also triggered divergence of their songs according to specific local habitat characteristics along both latitudinal and elevational gradients (Caro et al. 2013; Singh and Price 2015). Separation of gene pools can be a consequence.

We shortly return to the island example once more, because effects of any selective pressure on phenotype, behavior, and local gene pools are strongest and most visible in small isolated populations. In a comparative study, island songs strikingly did not differ in complexity from those of adjacent continental populations but included fewer features associated with aggressive behavior such as rattles, buzzes, and fast trills (Morinay et al. 2013). This stunning observation has been explained by reduced territoriality due to a lesser need of discrimination against closely related species in species-poor communities. Further insight on how competition might affect song variation came from a long-term study of Darwin's finches from the Galapagos Islands (Grant and Grant 2010). On Daphne Major, the finch community changed dramatically when in 1983 an alien species, Large Ground Finch Geospiza magnirostris, colonized the island and rapidly increased in numbers. In response to the invasion, the songs of the two native species (Common Cactus Finch G. scandens and Medium Ground Finch $G$. fortis) dramatically changed within a few years with respect to frequency bandwidth, trill rate, and song duration. These selective shifts of song characteristics went along with significant decrease of beak sizes due to competition with a larger species. This reciprocal effect is well-known, because in Darwin's finches, beak size correlates strongly with song characteristics (Podos 2001; Podos et al. 2004). A different story is told from the conquest of Galapagos by another invasive species: a parasitic fly, Philornis downsi, which in the 1960s was accidentally introduced to the archipelago. Finches infected by the parasites showed in many cases massive beak deformations, and mortality of nestlings and fledglings increased. Infected survivors had greater beaks; thus not only natural selection would act on feeding and foraging strategies, but also sexual selection would act on songs that would modify along with beak modifications (Kleindorfer and Dudaniec 2016). The reason is bird song is considered an honest signal of male quality (Gil and Gahr 2002; Spencer et al. 2003; Murphy et al. 2008). In our example, the infected males would be recognized by their aberrant songs, and females would thus avoid a risky parental investment and mate with a fitter male (Spencer et al. 2005; Bischoff et al. 2009). Such parasite-mediated sexual selection has been previously found for visual signals (e.g., phenotypical traits such as plumage coloration) and became better known as the Hamilton-Zuk hypothesis (Balenger and Zuk 2014). 


\subsection{Dialects as a Language Barrier and Isolating Mechanism}

Across a species' breeding range, variation of songs can change gradually and continuously along a cline. For example, in many species, frequency and time parameters of songs can clinally change with latitude or longitude (Tietze et al. 2011, 2015; Singh and Price 2015; see also ring species example in Fig. 5.3). This holds also true for comparisons across different species (Weir and Wheatcroft 2011; Tietze et al. 2015). On the other hand, large distribution gaps are often correlated with strong character discontinuities of songs, the most extreme examples being found on islands (see above). Already before the era of molecular systematics, a correlation between bioacoustic and genetic divergence has been assumed based on the example of North American Whitecrowned Sparrows Zonotrichia leucophrys (Baker 1975). Meanwhile, this interrelationship has been demonstrated in numerous case studies that came to a concordant conclusion: Divergence of song dialects contributes to speciation processes, e.g., in White-crowned Sparrows (MacDougall-Shackleton and MacDougall-Shackleton 2001; Toews 2017; Lipshutz et al. 2017) or in Mediterranean Subalpine Warblers Sylvia cantillans and allies (Brambilla et al. 2008). Another extreme and controversial example was reported from a so-called ring species, the Greenish Warbler Phylloscopus trochiloides. Ring species have a ring-shaped distribution around a geographic barrier such as continental waters or big mountains, like in our bird example the Tibetan Plateau (Fig. 5.3; for the theoretical background, see Martens and Päckert 2007). On each side of the barrier, biometric and bioacoustic traits change gradually along a chain of Greenish Warbler populations that are connected by gene flow. However, in a Siberian contact zone north of the plateau, gene pools and songs of the two terminal populations (viridanus in the West and plumbeitarsus in the East) differ dramatically (Irwin 2000; Irwin et al. 2001). Character divergence is as high that apparently gene flow between eastern and western Greenish Warblers is strongly limited due to a strong reproductive barrier (Alcaide et al. 2014). Strikingly, the effect of song dialects is not as strong as predicted by Irwin (2000), because a comprehensive study across the Siberian contact zone provided clear evidence of clinal variation of several frequency and time parameters of songs along a transect of recording sites (Kovylov et al. 2012). So, why would we find restricted gene flow despite apparent admixture of song dialects? In the next paragraph, we gain further insight in these processes from another Siberian contact zone.

\subsection{Sympathy in Sympatry: Bilingual Birds in a Hybrid Zone}

Spatial patterns of song dialects give us a clue not only on intraspecific variation but also putative premating barriers in areas of overlap where populations "of different languages" get into contact. The middle Amur valley of Far Eastern Russia is where two tit species meet: the yellow-bellied western Great Tit Parus major and the white- 


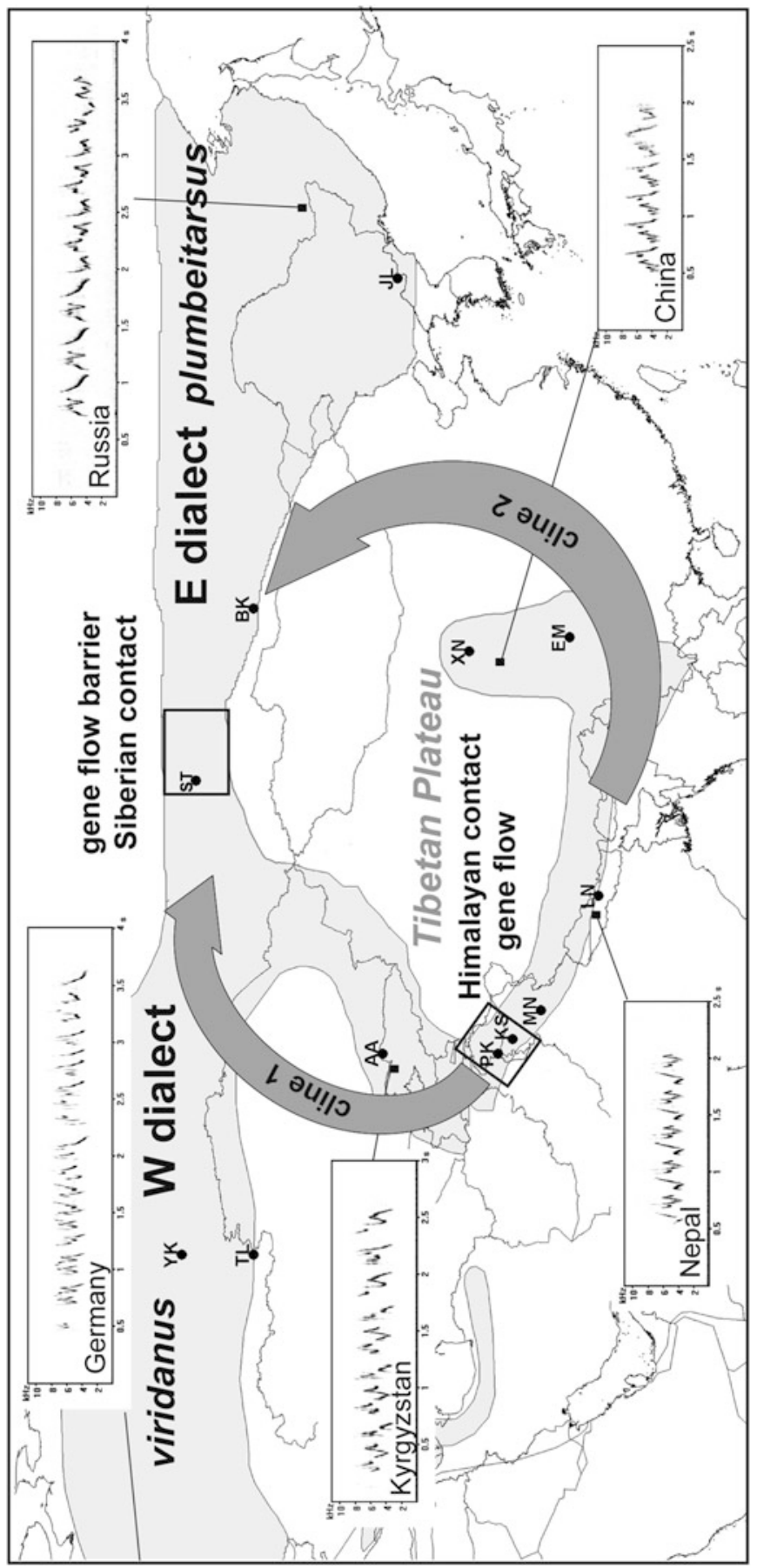

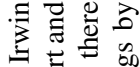

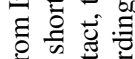
च 댈 焉 过 듕 에 茜要 $\stackrel{G}{\Xi} \dot{G}$

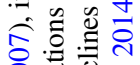
¿ू. = 要车

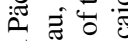

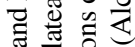

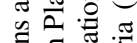
क्ष

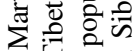
过 证通

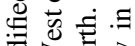

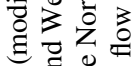

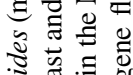

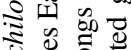
空

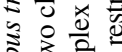
웡 है है

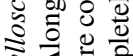
इ दे है 定安

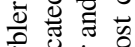

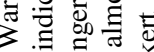

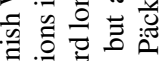

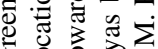
5응

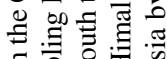
흘을 등 을. $\Xi . \exists$ क्षे 石 元

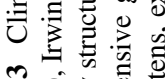

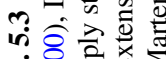

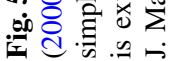




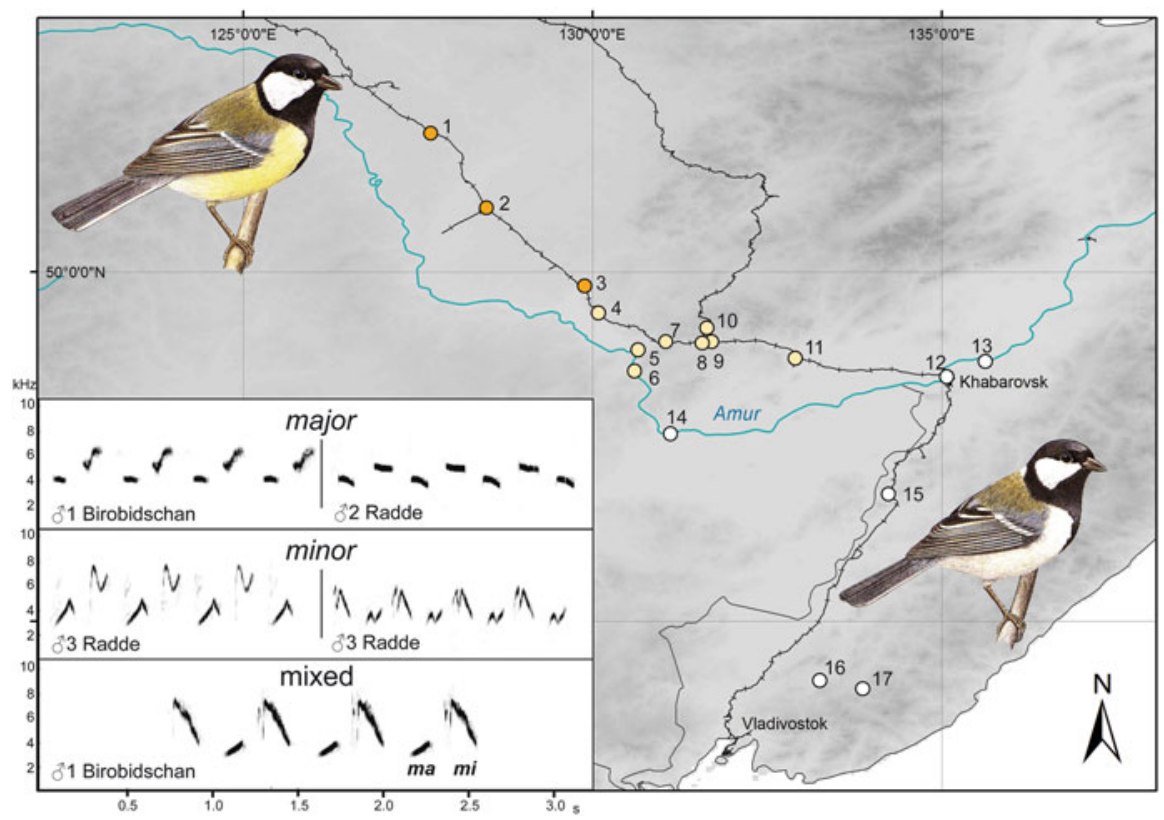

Fig. 5.4 Bilingual song repertoires in the Far East Russian hybrid zone of the yellow-bellied Great Tit Parus major (map, orange dots) and the white-bellied Japanese Tit $P$. minor (map, white dots; core zone of overlap, pale yellow dots). In the core zone of overlap, males can sing both major and minor song types, and they also display mixed songs composed of both note types; all recordings of M. Päckert, June 1996; population data from study sites 1-18 according to Päckert et al. (2005), Kvist and Rytkönen (2006), Fedorov et al. (2009); localities: $1=$ Shimanovsk, $2=$ Belogorsk, $3=$ Novobureysk, $4=$ Akhara, $5=$ Pashkovo, $6=$ Radde, $7=$ Obluchje, $8=$ Izvestkovyi, $9=$ Birakan, $10=$ Kuldur, $11=$ Birobidzhan (spelled "Birobidschan" in the sonograms), $12=$ Khabarovsk, $13=$ Maleshevo, $14=$ Amurzet, $15=$ Bikin, $16=$ Arsenev, $17=$ Buluga-Fadeyevo

bellied Japanese Tit $P$. minor. Songs of the two species are similar in syntax but differ fundamentally in the tonal quality of alternating notes (Fig. 5.4). Beyond the Amur valley, the different note repertoires seem to have an effect on species recognition, because playback of Asian minor songs does not provoke strong territorial reactions in European Great Tits-simply because the birds do not consider the Asian song their own language. The situation in the contact zone is different: There, from their first day in the nest, the young birds are reared in an acoustic environment where they can hear both European and Asian songs. As a consequence, in the middle Amur, male repertoires comprise both European and Asian song types and even mixed song types that combine notes of different tonal quality (Fig. 5.4; see also Martens 1996; Päckert et al. 2005). The juvenile birds effectively received a bilingual education! These mixed repertoires confirmed what could already be observed in the field about 100 years before: There is a lot of hybridization going on between Great and Japanese Tits in the middle Amur, 
because local populations include a high percentage of individuals with intermediate plumage coloration-a yellow-tinge of all tones.

Analysis of local song repertoires revealed another striking thing: All bilingual males had yellow plumage to a certain degree, whereas almost all purely white minor birds sang pure Asian minor dialect (Päckert et al. 2005). So for some reason, the yellow major birds and their hybrids are better learners. This apparently has an effect on female choice, because like in other bird species, female Great Tits seem to prefer males with larger and more variable repertoires (McGregor and Krebs 1982; Baker et al. 1986). It was thus not surprising that most solitary males in the middle Amur populations were white (Nazarenko et al. 1999): The lazy learners were apparently less attractive to females and had to go solo. Olofsson and Servedio (2008) postulated that female preference for mixed repertoires could act as a positive feedback mechanism and as a selective pressure on repertoire composition. In conclusion, they considered sympatry an effective driver of cultural evolution.

Such bias in female mating preferences is also called assortative mating, and this is rather the rule than the exception in avian hybrid zones. At a closer look, the situation of the two Russian tit species is perfectly paralleled in other hybrid zones, such as in the eastern European contact area of the European Pied Flycatcher Ficedula hypoleuca and the Collared Flycatcher F. albicollis. There, the majority of male Pied Flycatchers (65\%) include various parts of Collared Flycatcher song in their song repertoire, but not vice versa (Qvarnström et al. 2006). From individual mixed repertoires, researchers could make exact predictions on hybridization: female Collared Flycatchers only paired with Pied Flycatchers when they were mixed singers (Haavie et al. 2004).

Limited or asymmetric gene flow due to song-biased assortative mating has also been shown in two contact zones between two species of chiffchaffs in the Pyrenees (Phylloscopus collybita, P. ibericus: Helbig et al. 2001) and between two subspecies of $P$. collybita in western Siberia (Shipilina et al. 2017). All these examples impressively demonstrate a strong effect of the variation of learned vocal signals on species recognition, mate choice, and thus gene flow among populations of what one observer would consider the same species whereas others would speak of two species. In fact, these borderline cases are the most fascinating examples to study speciation in action in the field.

Acknowledgments I would like to thank Jochen Martens for his helpful comments on the manuscript.

\section{References}

Alcaide M, Scordato ESC, Price TD, Irwin DE (2014) Genomic divergence in a ring species complex. Nature 511(7507):83-85

Amy M, Salvin P, Naguib M, Leboucher G (2015) Female signalling to male song in the domestic canary, Serinus canaria. R Soc Open Sci 2(1):140196 
Araya-Salas M, Wright T (2013) Open-ended song learning in a hummingbird. Biol Lett 9 (5):20130625

Azar JF, Bell BD (2016) Acoustic features within a forest bird community of native and introduced species in New Zealand. Emu 116(1):22-31

Baker MC (1975) Song dialects and genetic differences in white-crowned sparrows (Zonotrichia leucophrys). Evolution 29(2):226-241

Baker MC, Bjerke TK, Lampe H, Espmark YO (1986) Sexual response of female great tits to variation in size of males' song repertoires. Am Nat 128(4):491-498

Baker MC, Baker MSA, Tilghman LM (2006) Differing effects of isolation on evolution of bird songs: examples from an island-mainland comparison of three species. Biol J Linn Soc Lond 89 (2):331-342

Balenger SL, Zuk M (2014) Testing the Hamilton-Zuk hypothesis: past, present and future. Inegr Comp Biol 54(4):601-613

Barker NKS, Menill DJ (2009) Song perch height in Rufous-and-white Wrens: does behaviour enhance effective communication in a tropical forest? Ethology 115(9):897-904

Bischoff LL, Tschirren B, Richner H (2009) Long-term effects of early parasite exposure on song duration and singing strategy in great tits. Behav Ecol 20(2):265-270

Brambilla M, Janni O, Guidali F, Soraces A (2008) Song perception among incipient species as a mechanism for reproductive isolation. J Evol Biol 21(3):651-657

Caro LM, Caycedo-Rosales PC, Bowie RC, Slabbekoorn H, Cadena CD (2013) Ecological speciation along an elevational gradient in a tropical passerine bird? J Evol Biol 26(2):357-374

Catchpole CK (1980) Sexual selection and the evolution of complex songs among European warblers of genus Acrocephalus. Behaviour 74(1):149-166

Catchpole CK (1986) Song repertoires and reproductive success in the great reed warbler Acrocephalus arundinaceus. Behav Ecol Sociobiol 19(6):439-445

Catchpole CK, Leisler B (1996) Female aquatic warblers (Acrocephalus paludicola) are attracted by playback of longer and more complicated songs. Behaviour 133(15):1153-1164

Catchpole CK, Slater PJB (1995) Bird song - biological themes and variations. Cambridge University Press, Cambride

Constantine \& The Sound Approach (2006) The sound approach to birding - a guide to understanding bird sound. The Sound Approach, Dorset

Corning PA (2014) Evolution 'on purpose': how behaviour has shaped the evolutionary process. Biol J Linn Soc 112(2):242-260

Creanza N, Fogarty L, Feldman MW (2016) Cultural niche construction of repertoire size and learning strategies in songbirds. Evol Ecol 30(2):285-305

Dahlin CR, Wright TF (2012) Duet function in the yellow-naped amazon, Amazona auropalliata: evidence from playbacks of duets and solos. Ethology 118(1):95-105

Danner JE, Danner RM, Bonier F, Martin PR, Small TW, Moore IT (2011) Female, but not male, tropical sparrows respond more strongly to the local song dialect: implications for population divergence. Am Nat 178(1):53-63

Darolová A, Krištofík J, Hoi H, Wink M (2012) Song complexity in male marsh warblers: does it reflect male quality? J Ornithol 153(2):431-439

deBoer RA, Eens M, Müller W (2016) 'Out of tune': consequences of inbreeding on bird song. Proc R Soc Lond B 283(1835):20161142

Dowsett-Lemaire F (1979) The imitative range of the song of the marsh warbler, Acrocephalus palustris, with special reference to imitations of African birds. Ibis 121(4):453-468

Eens M, Pinxten R, Verheyen RF (1992) Song learning in captive European starlings, Sturnus vulgaris. Anim Behav 44(6):1131-1134

Fedorov VV, Surin VL, Valchuk OP, Kapitonova LP, Kerimov AB, Formozov NA (2009) Maintaining morphological specificity and genetic introgression in populations of the great tit Parus major and the Japanese tit P. minor in the Middle Amur region. Russ J Genet 45 (7):771-780 
Ficken MS, Rusch KM, Taylor AJ, Powers DR (2000) Blue-throated hummingbird song: a pinnacle of nonoscine vocalizations. Auk 117(1):120-128

Forstmeier W, Leisler B (2004) Repertoire size, sexual selection, and offspring viability in the great reed warbler: changing patterns in space and time. Behav Ecol 15(4):555-563

Gahr M (2000) Neural song control system of hummingbirds: comparison to swifts, vocal learning (Songbirds) and nonlearning (Suboscines) passerines, and vocal learning (Budgerigars) and nonlearning (Dove, owl, gull, quail, chicken) nonpasserines. Comp Neurol 426(2):182-196

Gil D, Gahr M (2002) The honesty of bird song: multiple constraints for multiple traits. Trends Ecol Evol 17(3):133-141

Grant BR, Grant PR (2010) Songs of Darwin's finches diverge when a new species enters the community. PNAS 107(47):20156-20163

Haavie J, Borge T, Bureš S, Garamszegi LZ, Lampe HM, Moreno J, Qvarnström A, Török J, Sætre GP (2004) Flycatcher song in allopatry and sympatry - convergence, divergence and reinforcement. J Evol Biol 17(2):227-237

Hall ML (2009) A review of vocal duetting in birds. Adv Study Behav 40:67-21

Helbig AJ, Salomon M, Bensch S, Seibold I (2001) Male-biased gene-flow across an avian hybrid zone: evidence from mitochondrial and microsatellite DNA. J Evol Biol 14(2):277-287

Hultsch H, Todt D (2004) Learning to sing. In: Marler P, Slabbekoorn H (eds) Nature's music - the science of birdsong. Elsevier Academic, London, pp 80-107

Hunter ML, Krebs JR (1979) Geographical variation in the song of the great tit (Parus major) in relation to ecological factors. J Anim Ecol 48(3):759-785

Irwin DE (2000) Song variation in an avian ring species. Evolution 54(3):998-1010

Irwin DE, Price T (2009) Sexual imprinting learning and speciation. Heredity 82(4):347-354

Irwin DE, Bensch S, Price TD (2001) Speciation in a ring. Nature 409(6818):333-337

Jarvis ED (2006) Evolution of brain structures for vocal learning in birds: a synopsis. Act Zool Sin 52(suppl):85-89

Jetz W, Thomas GH, Joy JB, Hartmann K, Mooers AO (2012) The global diversity of birds in space and time. Nature 491(7424):444-448

Kleindorfer S, Dudaniec RY (2016) Host-parasite ecology, behavior and genetics: a review of the introduced fly parasite Philornis downsi and its Darwin's finch hosts. BMC Zool 1:1

Kovylov NS, Marova IM, Ivanitsky VV (2012) Variation of song and plumage of the western (Phylloscopus trochiloides viridanus) and eastern (Phylloscopus trochiloides plumbeitarsus) forms of greenish warbler in sympatry zone: whether the hypothesis of ring speciation is true? Biol Bull 39(9):729-740

Kroodsma D (2004) The diversity and plasticity of birdsong. In: Marler P, Slabbekoorn H (eds) Nature's music - the science of birdsong. Elsevier Academic, London, pp 108-131

Kvist L, Rytkönen S (2006) Characterization of a secondary contact zone of the Great tit Parus major and the Japanese tit $P$. minor (Aves: Passeriformes) in Far Eastern Siberia with DNA markers. Zootaxa 1325:55-73

Lachlan RF, Servedio MR (2004) Song learning accelerates allopatric speciation. Evolution 58 (9):2049-2063

Lachlan RF, Verzijden MN, Bernhard CS, Jonker P-P, Koese B, Jaarsma S, Spoor W, Slater PJB, ten Cate C (2013) The progressive loss of syntactical structure in bird song along an island colonization chain. Curr Biol 23(19):1896-1901

Lipshutz SE, Overcast IA, Hickerson MJ, Brumfield RT, Derryberry EP (2017) Behavioural response to song and genetic divergence in two subspecies of white-crowned sparrows (Zonotrichia leucophrys). Mol Ecol 26(11):3011-3027

Logue DM, Hall ML (2014) Migration and the evolution of duetting in songbirds. Proc R Soc Lond B 281(1782):20140103

Logue DM, Krupp DB (2016) Duetting as a collective behavior. Front Ecol Evol 4:7

Luther D (2009) The influence of the acoustic community on songs of birds in a neotropical rain forest. Behav Ecol 20(4):864-871 
Lynch A (1996) The population memetics of birdsong. In: Kroodsma DE, Miller EH (eds) Ecology and evolution of acoustic communication in birds. Cornell University Press, Ithaca, NY, pp 221-240

MacDougall-Shackleton EA, MacDougall-Shackleton SA (2001) Cultural and genetic evolution in mountain white-crowned sparrows: song dialects are associated with population structure. Evolution 55(12):2568-2575

Mahler B, Gil D (2009) The evolution of song in the Phylloscopus leaf warblers (Aves: Sylviidae): a tale of sexual selection, habitat adaptation, and morphological constraints. Adv Study Behav 40:35-66

Marler P (2004a) Science and birdsong: the good old days. In: Marler P, Slabbekoorn H (eds) Nature's music - the science of birdsong. Elsevier Academic, London, pp 1-38

Marler P (2004b) Bird calls: a cornucopia for communication. In: Marler P, Slabbekoorn H (eds) Nature's music - the science of birdsong. Elsevier Academic, London, pp 132-177

Marler P, Slabbekoorn H (eds) (2004) Nature's music - the science of birdsong. Elsevier Academic, London

Martens J (1996) Vocalization and speciation of Palearctic birds. In: Kroodsma DE, Miller EH (eds) Ecology and evolution of acoustic communication in birds. Cornell University Press, Ithaca, NY, pp 221-240

Martens J (1998) Geographische Variabilität der Lautäußerungen von Sperlingsvögeln - Auswirkungen auf Artbildung und das Artkonzept (Aves: Passeriformes: Oscines). In: Eck (ed) 100 Jahre Artkonzepte in der Biologie. Zool Abh Mus Tierk Dresden 50(suppl):35-50

Martens J, Päckert M (2007) Ring species - do they exist in birds? Zool Anz 246(4):315-324

Martens J, Päckert M, Nazarenko A, Valchuk O, Kawaji N (1998) Comparative bioacoustics of territorial song in the Goldcrest (Regulus regulus) and its implications for the intrageneric phylogeny of the genus Regulus. Zool Abh Mus Tierkd Dresden 50(7):99-128

Mason NA, Burns KJ, Tobias JA, Claramunt S, Seddon N, Derryberry EP (2017) Song evolution, speciation and vocal learning in passerine birds. Evolution 71(3):786-796

McGregor PK, Krebs JR (1982) Mating and song types in the great tit. Nature 297:60-61

Morinay J, Cardoso GC, Doutrelant C, Covas R (2013) The evolution of birdsong on islands. Ecol Evol 3(16):5127-5140

Murphy MT, Sexton K, Dolan ACD, Redmont LJ (2008) Dawn song of the eastern kingbird: an honest signal of male quality? Anim Behav 75(3):1075-1084

Nazarenko AA, Valchuk O, Martens J (1999) Secondary contact and overlap of Parus major and Parus minor populations in the middle Amur River basin. Zool Zhurn 78(3):371-381

Nemeth E, Winkler H, Dabelsteen T (2001) Differential degradation of antbird songs in a neotropical rainforest: adaptation to perch height? J Acoust Soc Am 110(6):3263-3274

Nicolai J, Gundacker C, Teeselink K, Güttinger HR (2014) Human melody singing by bullfinches (Pyrrhula pyrrhula) gives hints about a cognitive note sequence processing. Anim Cogn 17 (1): $143-155$

Nottebohm F (1968) Auditory experience and song development in the chaffinch Fringilla coelebs. Ibis 110(4):549-568

Nottebohm F (1969) The "critical period" for song learning in birds. Ibis 111(3):386-387

Nottebohm F (1970) Ontogeny of bird song. Science 167(3920):950-956

Nottebohm F (1971) Neural lateralization of vocal control in a passerine bird song. J Exp Zool 177 (2):229-262

Nowicki S, Searcy WA (2014) The evolution of vocal learning. Curr Opin Neurobiol 28:48-53

Nowicki S, Peters S, Podos J (1998) Song learning, early nutrition and sexual selection in songbirds. Am Zool 38(1):179-190

O'Loghlen AL, Beecher MD (1997) Sexual preferences for mate song types in female song sparrows. Anim Behav 53(4):835-841

Odom KJ, Hall ML, Riebel K, Omland KE, Langmore NE (2014) Female song is widespread and ancestral in songbirds. Nat Commun 5:3379 
Olofsson H, Servedio MR (2008) Sympatry affects the evolution of genetic versus cultural determination of song. Behav Ecol 19(3):596-604

Päckert M, Martens J (2004) Song dialects on the Atlantic islands: goldcrests of the Azores (Regulus regulus azoricus, $R$. $r$. sanctae-mariae, $R$. $r$. inermis). J Ornithol 145(1):23-30

Päckert M, Martens J, Hofmeister T (2001) Lautäußerungen der Sommergoldhähnchen von den Inseln Madeira und Mallorca (Regulus ignicapillus madeirensis, $R$. i. balearicus). J Ornithol 142(1):16-29

Päckert M, Martens J, Nazarenko AA, Kosuch J, Veith M (2003) Phylogenetic signal in song of crests and kinglets (Aves: Regulus). Evolution 57(3):616-629

Päckert M, Martens J, Sun YH, Veith M (2004) The radiation of the Seicercus burkii complex and its congeners - molecular genetics and bioacoustics. Org Divers Evol 4(4):341-364

Päckert M, Martens J, Nazarenko AA, Valchuk O, Petri B, Eck S, Veith M (2005) The great tit, Parus major, a misclassified ring species. Biol J Linn Soc 86(2):153-174

Päckert M, Martens J, Severinghaus LL (2009) The Taiwan Firecrest (Regulus goodfellowi) belongs to the Goldcrest assemblage (Regulus regulus s. 1.) - evidence from mitochondrial DNA and territorial song of the Regulidae. J Ornithol 150(1):205-220

Pepperberg IM (2004) Grey parrots: learning and using speech. In: Marler P, Slabbekoorn H (eds) Nature's music - the science of birdsong. Elsevier Academic, London, pp 363-373

Pepperberg IM (2010) Vocal learning in grey parrots: a brief review of perception, production, and cross-species comparisons. Brain Lang 115(1):81-91

Petrusková T, Diblíková L, Pipek P, Frauendorf E, Procházka P, Petrusek A (2015) A review of the distribution of Yellowhammer (Emberiza citrinella) dialects in Europe reveals the lack of a clear macrogeographic pattern. J Ornithol 156(1):263-273

Pipek P, Petrusková T, Petrusek A, Diblíková L, Eaton MA, Pyšek P (2017) Dialects of an invasive songbird are preserved in its invaded but not native source range. Ecography 40:001-009

Podos J (2001) Correlated evolution of morphology and vocal signal structure in Darwin's finches. Nature 409(6817):185-188

Podos J, Southall JA, Rossi-Santos MR (2004) Vocal mechanics in Darwin's finches: correlation of beak gape and song frequency. J Exp Biol 207(4):607-619

Potvin DA, Clegg SM (2015) The relative roles of cultural drift and acoustic adaptation in shaping syllable repertoires of island bird populations change with time since colonization. Evolution 69 (2):368-380

Price JJ (2015) Rethinking our assumptions about the evolution of bird song and other sexually dimorphic signals. Front Ecol Evol 3:Article 40

Prum RO (2012) Aesthetic evolution by mate choice: Darwin's really dangerous idea. Philos Trans R Soc B 367(1600):2253-2265

Purushotham CB, Robin VV (2016) Sky island bird populations isolated by ancient genetic barriers are characterized by different song traits than those isolated by recent deforestation. Ecol Evol 6 (20):7334-7343

Pusey A, Wolf M (1996) Inbreeding avoidance in animals. Trend Ecol Evol 11(5):201-206

Qvarnström A, Haavie J, Sæther SA, Eriksson D, Pärt T (2006) Song similarity predicts hybridization in flycatchers. J Evol Biol 19(4):1202-1209

Reid JM, Arcese P, Cassidy ALE, Hieberts SM, Smith JNM, Stoddard PK, Marr AB, Keller LF (2004) Song repertoire size predicts initial mating success in male song sparrows, Melospiza melodia. Anim Behav 68(5):1055-1063

Rheindt FE, Grafe TU, Abouheif E (2014) Rapidly evolving traits and the comparative method: how important is testing for phylogenetic signal? Evol Ecol Res 6(3):377-396

Riebel K, Lachlan RF, Slater PJB (2015) Learning and cultural transmission in chaffinch song. In: Naguib M, Brockmann HJ, Mitani JC, Simmons LW, Barrett L, Healy S, PJB S (eds) Advances in the study of behavior, vol 47. Elsevier Science, San Diego, pp 181-227

Shipilina D, Serbyn M, Ivanitskii V, Marova I, Backström N (2017) Patterns of genetic, phenotypic, and acoustic variation across a chiffchaff (Phylloscopus collybita abietinus/tristis) hybrid zone. Ecol Evol 7(7):2169-2180 
Singh P, Price TD (2015) Causes of the latitudinal gradient in birdsong complexity assessed from geographical variation within two Himalayan warbler species. Ibis 157(3):511-527

Slabbekoorn H (2004) Singing in the wild: the ecology of birdsong. In: Marler P, Slabbekoorn H (eds) Nature's music - the science of birdsong. Elsevier Academic, London, pp 178-206

Slabbekoorn H, Smith TB (2002) Bird song, ecology and speciation. Philos Trans R Soc Lond B 357(1420):493-503

Spencer KA, Buchanan KL, Goldsmith AR, Catchpole CK (2003) Song as an honest signal of developmental stress in the zebra finch (Taeniopygia guttata). Horm Behav 44(2):132-139

Spencer KA, Buchanan KL, Leitner S, Goldsmith AR, Catchpole CK (2005) Parasites affect song complexity and neural development in a songbird. R Proc Soc Lond B 272(1576):2037-2043

Suh A, Paus M, Kiefmann M, Churakov G, Franke FA, Brosius J, Kriegs JO, Schmitz J (2011) Mesozoic retroposons reveal parrots as the closest living relatives of passerine birds. Nat Commun 2:443

Thaler E (1990) Die Goldhähnchen. Neue Brehm Bücherei, Lutherstadt Wittenberg

Thielcke G (1970) Lernen von Gesang als möglicher Schrittmacher der Evolution. Z Zool Syst Evolutionsforsch 8(1):309-320

Thielcke G (1972) On the origin of divergence of learned signals (songs) in isolated populations. Ibis 115(4):511-516

Thorpe WH (1958) The learning of song patterns by birds, with especial reference to the song of the chaffinch Fringilla coelebs. Ibis 100(4):535-570

Tietze DT, Martens J, Sun Y-H, Päckert M (2008) Evolutionary history of treecreeper vocalisations (Aves: Certhia). Org Divers Evol 8(4):305-324

Tietze DT, Martens J, Sun YH, Severinghaus LL, Päckert M (2011) Song evolution in the Coal Tit. J Avian Biol 42(3):214-230

Tietze DT, Martens J, Fischer BS, Sun Y-H, Klussmann-Kolb A, Päckert M (2015) Evolution of leaf-warbler songs (Aves: Phylloscopidae). Ecol Evol 5(3):781-798

Tobias JA, Gamarra-Toldeo V, Carcía-Olachea D, Pulgarín PC, Seddon N (2011) Year-round resource defence and the evolution of male and female song in suboscine birds: social armaments are mutual ornaments. J Evol Biol 24(10):2118-2138

Toews DPL (2017) From song dialects to speciation in white-crowned sparrows. Mol Ecol 26 (11):2842-2844

Verzijden MN, ten Cate C, Servedio MR, Kozak GM, Boughman JW, Svensson EI (2012) The impact of learning on sexual selection and speciation. Trends Ecol Evol 27(9):511-519

Voigt C, Leitner S, Gahr M (2006) Repertoire and structure of duet and solo songs in cooperatively breeding white-browed sparrow weavers. Behaviour 143(2):159-182

Wegrzyn E, Leniowski K (2009) Syllable sharing and changes in syllable repertoire size and composition within and between years in the great reed warbler. J Ornithol 151(2):255-267

Weir JT, Wheatcroft D (2011) A latitudinal gradient in rates of evolution of avian syllable diversity and song length. Proc R Soc Lond B 278(2712):1713-1720

Open Access This chapter is licensed under the terms of the Creative Commons Attribution 4.0 International License (http://creativecommons.org/licenses/by/4.0/), which permits use, sharing, adaptation, distribution and reproduction in any medium or format, as long as you give appropriate credit to the original author(s) and the source, provide a link to the Creative Commons license and indicate if changes were made.

The images or other third party material in this chapter are included in the chapter's Creative Commons license, unless indicated otherwise in a credit line to the material. If material is not included in the chapter's Creative Commons license and your intended use is not permitted by statutory regulation or exceeds the permitted use, you will need to obtain permission directly from the copyright holder.

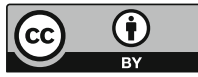

